\title{
菌根霟胞による骨の直接的吸収に関する実験的研究
}

\author{
角田左武郎・松 本 英彦・加藤 和子 \\ 吉 村 節・倉 地 洋一・南雲正男
}

\section{Experimental studies on direct bone resorption by radicular cyst in vitro}

\author{
Saburo Kakuta - Hidehiko Matsumoto - Kazuko Kato \\ Setsu Yoshimura $=$ Yoichi Kuraghi - Masao Nagumo
}

緒

言

歯原性䨌胞は顎骨内に発生し, 周团の顎骨組織を吸収 して增大していくと考穴られる。，その機序として，六進 した堙胞内圧が骨吸収を促進し, 垔胞が増大すると理解 されている1,2). したがって簬胞に関する生化学的研究 の多くは, 䙵胞内溶夜の分析, あるいは停滞機構などに 集中していた ${ }^{3 \sim 5)}$

最近, 鈴木ら ${ }^{6)}$ は裂胞内溶液を分析した結果, 雚胞壁

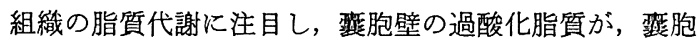
の増大に関与することを推測した。 また，Harris らは， 蹤壁組織を培養すると，培地中に prostaglandins (PGs) 様物質が放出され，この物質が in vitro で骨組織を吸収 する能力のあることを示した ${ }^{7 \sim 9)}$.

一方, Eilon $ら^{(0)}$ は腫瘍細胞が, Oguchi ${ }^{11)}$ は歯根吸収 組織が，Mundy'12)，Kahn ${ }^{13,14) ， あ る い は ~ M c A r t h u r ~}$

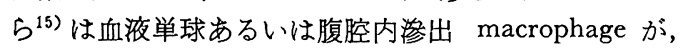
直接骨組織を吸収する能力のあることを in vitro で証明 している。このことは, 破骨細胞以外の細胞, あるいは 組織が骨組織を吸収する能力のあることを示唆している と思われる。

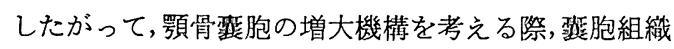
が破骨細胞を活性化する因子を放出して，間接的に周囲

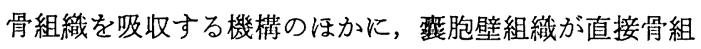
織を吸収する機構の存在も考虑すべきであると考兄る。 そこで，われわれは買領域で頻繁に遭遇する歯根烮胞を 用い, in vitro の系で翌胞組織に骨吸収能があるかどう かを検討したので報告する。

昭和大学遒学部第 2 口腔外科学教室（主任：南雲正男 教授）

The Second Department of Oral Surgery, School of Dentistry, Showa University (Chief: Prof. Masao Nagumo)

受付日：炤和56年 7 月 24 日

\section{実 験 方 法}

実験材料：採取した歯根裂胞をPBS (200U/ml: penicillin-G, $1 \mathrm{mg} / \mathrm{ml}$ : streptmycin を含む) で十分に洗浄

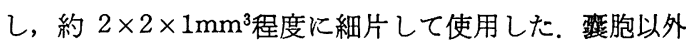
の組織としては, 臨床的に発赤の認められる歯肉, 智歯

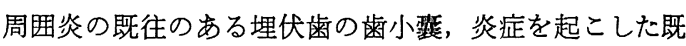
往のない正中過剰埋伏歯の歯小雚, および rat の肝臓を 同様に細片化して実験に使用し，歯根娈胞組織と比較検 討した。

骨吸収の実験：骨吸収の実験はOguchi ${ }^{11)}$ の方法に準 じて行った. すなわち, 体重約 $50 \mathrm{~g}$ 前後の wister 系雄 性 rat の腹腔内に ${ }^{45} \mathrm{Ca}$ を $50 \mu \mathrm{ci}$ (specific activity: 24 $\mathrm{Ci} / \mathrm{m}$ mole) 注入し, 1 週間飼育したのち断頭し, 頭頂 骨を取り出した．この一対の頭頂骨を $-20^{\circ} \mathrm{C}$ で凍結保 存し, 細胞成分を死滅させ，16等分し実験に使用した。 この頭頂骨には， ${ }^{3} \mathrm{H}$-proline を一緒に培養しても取り 込みが認められないことを，予備実験によってあらかじ め確認した。.このことは，この頭頂骨は蛋白合成能がな く細胞成分が死滅していることを意味している.

骨吸収の実験に先立って，16等分された骨組織を stainless steel mesh の入った直径約 $6 \mathrm{~cm}$ の Falcon plastic dish に入れ, 初めは $2 \mathrm{ml}$ の $\mathrm{PBS}(200 \mathrm{U} / \mathrm{ml}$ : penicillin$\mathrm{G}, 1 \mathrm{mg} / \mathrm{ml}$ : streptmycin を含む) を steel mesh に乗 せた骨組織が浸るように加えて 24 時間放置した。つい で, $\mathrm{Ca}^{2+}$ が終濃度で $1.26 \mathrm{mM}$ になるように調整した Ham F 12 培地 $(20 \mathrm{U} / \mathrm{ml}$ : penicillin-G, $100 \mu \mathrm{g} / \mathrm{ml}$ : streptmycin, 10\%仔牛血清 : CCS を含む) を加えて, 24 時間 $5 \% \mathrm{CO}_{2}, 95 \%$ 空気で炭酸ガス培羕器にて前培 羕を行い，結合の弱い ${ }^{45} \mathrm{Ca}$ を除去した。骨吸収の実験 は，前培養した頭頂骨を図1のように袈壁組織ではさみ 込み, 上述の Ham F 12 培地を $2 \mathrm{ml}$ 加えて 3 日間培養 して行った.

培地は毎日交換し，その際得られる古い培地を検体と し, 蒸留水 $2.5 \mathrm{ml}$ 特よび Instagel $5.5 \mathrm{ml}$ (Packard社) 


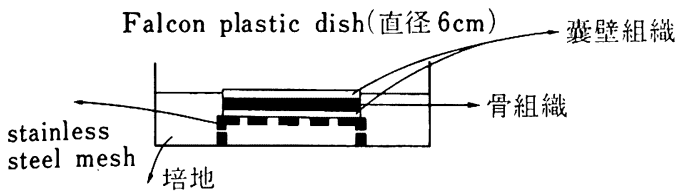

Ham F 12

図 1 夷験力法

(20U/ml: penicillin $\mathrm{G}$

$100 \mu \mathrm{g} / \mathrm{ml}:$ streptmycin

10\%: CCS

1. $26 \mathrm{mM}: \mathrm{Ca}^{2+}$

培善条件

$5 \% \mathrm{CO}_{2} 95 \%$ 空気 $37^{\circ} \mathrm{C}$

を加えて liquid scintillation counter で培地に放出され た ${ }^{45} \mathrm{Ca}$ を測定し，骨吸収能を検討した。骨吸収能は $\mathrm{cpm}$ 值, または何の組織も加えない対照群の $\mathrm{cpm}$ 值と の比であらわした，培養期間中の培地の $\mathrm{pH}$ の変動は 7.1 から 7.4 の間であり，極端に acidosis になること はなかった。

組織への ${ }^{3}$ H-proline 取り込み 培養中に襞壁組織が 生きていれば，蛋白合成が行われると考光， ${ }^{3} \mathrm{H}$-proline の組織への取り込み能を検討した。 ${ }^{45} \mathrm{Ca}$ を取り込ませ ていない頭頂骨とともに組織を培養し，培養 1 日目， 2 日目， 3 日目， 4 日目に ${ }^{3} \mathrm{H}$-proline $20 \mu \mathrm{ci}$ (specific activity: $5 \mathrm{Ci} / \mathrm{m}$ mole) とそれぞれの dish に入れ 24 時 間培養して ${ }^{3} \mathrm{H}$-proline の取り込みを検討した。培地は $10 \%$ CCS を含む Eagle's MEM 培地 $2 \mathrm{~m} l$ を用い, 培養は $5 \% \mathrm{CO}_{2}, 95 \%$ 空気で炭酸ガス培養器で行った。

培養後, 覇胞組織片を取り出して PBS で洗浄し $0.5 \mathrm{~N}$ 酶酸 $1 \mathrm{ml}$ を加えて十分にホモジナイズした。 ついで, 培養夜とホモジネートを一緒にして約 1,000 倍の $0.5 \mathrm{~N}$ 酶酸で透析した。透析外液の ${ }^{3} \mathrm{H}$-proline のレベルがほ とんど消失するまで透析液を頻回に交換したのち，内液 の ${ }^{3} \mathrm{H}$-proline 量を liquid scintillation counter で測定 して蛋白合成能を検討した。

\section{結果}

歯根蕒胞による骨吸収について：整胞壁組織片で骨組 織をはさみ込み，3 日間培養し骨吸収能を検討したのが 図 2 である，何の組織も乗せていない対照群と比較し， 骨吸収が促進していることが確かめられた。

図3は1日量の变化を実験群と対照群で比較したもの である. 培養期間中, その比は $1.24,1.21,1.25$ と大 きな変動は認められなかった。この現象の原因として， 骨組織をはさみ込んだといら物理的刺激により骨組織が 吸収されたといら可能性が考えられる。 そこで震胞壁組 織を $100^{\circ} \mathrm{C}$ で1分間熱処理し, 新鮮な組織と比較検討

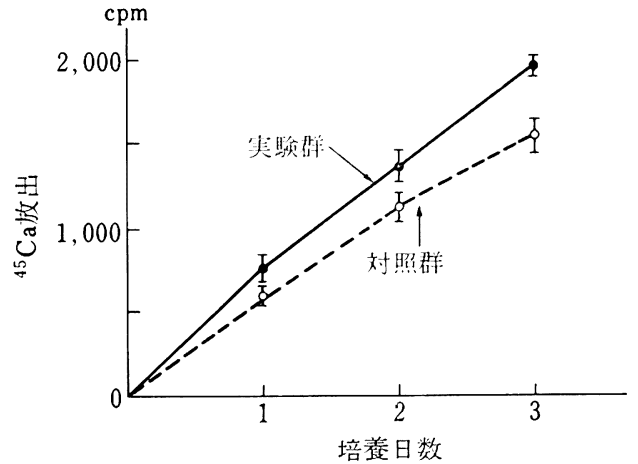

図 2 碀根型壁組織による骨吸収。実験は triplecate 行い平均值 $\pm \mathrm{SD} ゙$ 示した。

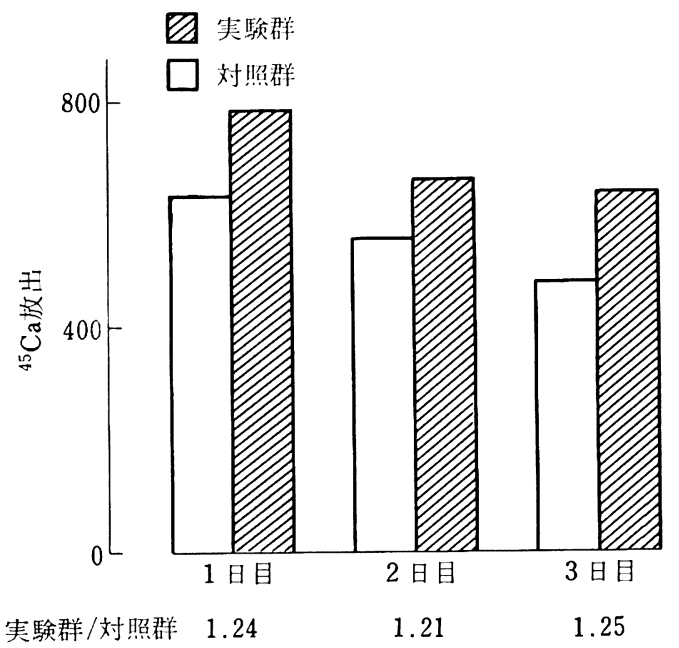

図 3 整壁組織群捺よび対照群の1日量の変 化。下段はその比を示す。

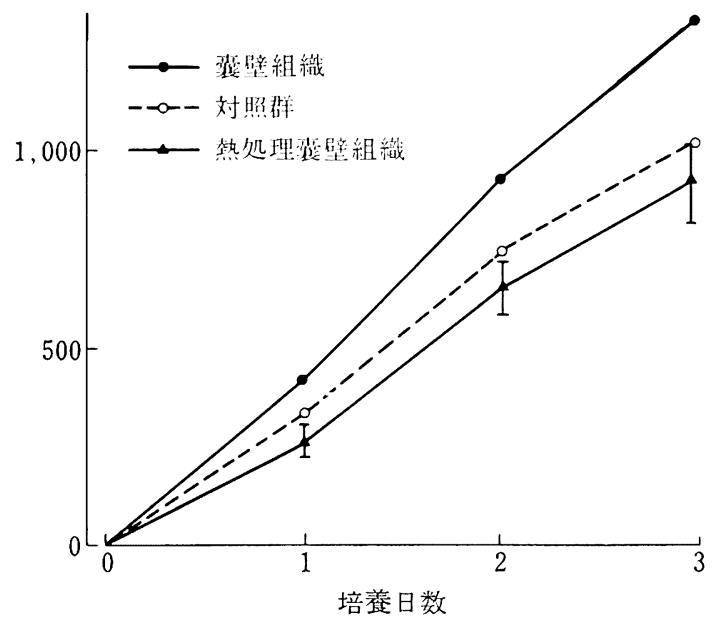

図 4 熱処理脡壁組織の骨組織に対与る効果。熱 処理群のみ triplecate 行っている。他の群は duplecate. 
表 1 薄胞と骨組織の接触関係

\begin{tabular}{c|c}
\hline 接触関係 & 实験群 / 対照群 \\
\hline 両面接触群 & $1.25 \pm 0.06(12)$ \\
\hline 非接 触 群 & $1.11 \pm 0.06(3)$ \\
\hline
\end{tabular}

平均値 ISD (n)

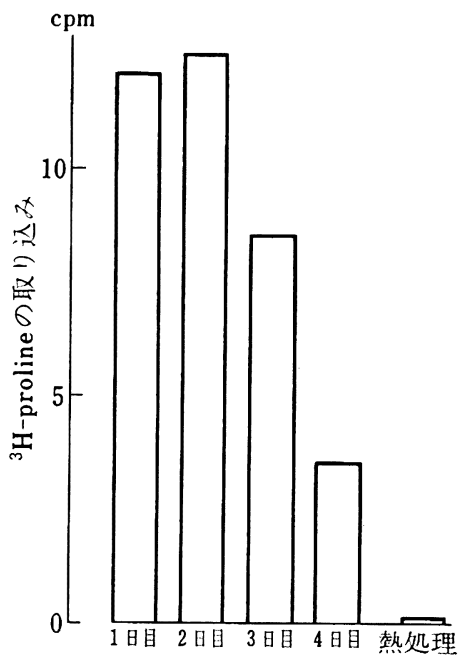

図 5 溼壁組織による ${ }^{3} \mathrm{H}$-proline の 取り込み。対照は組織に熱処理 を加えて 24 時間培数し, ${ }^{3} \mathrm{H}$ proline の取り込みを測定。

表 2 各種組織片による骨吸収

\begin{tabular}{|c|c|c|}
\hline 組 織 & 炎症 & 実験群 / 対照群 \\
\hline 歯 肉 & + & $1.28 \pm 0.04(3)$ \\
\hline \multicolumn{3}{|l|}{ 困小露 } \\
\hline 下顎智这 & + & 1.29 \\
\hline 正中過剩蔽 & - & 1. 10 \\
\hline ラット盰缄 & - & 0.88 \\
\hline 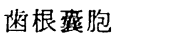 & + & $1.25 \pm 0.06(11)$ \\
\hline
\end{tabular}

平均值土 $\mathrm{SD}(\mathrm{n})$

したのが図 4 である。図より明らかなように，熱処理を 加えた群は対照群と大差なく, 逆に低下傾向が認められ た.

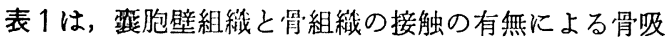
収の差異を㭘討したものである。接触群では対照群の 1.26倍なのに対して，骨組織と聚壁組織を遠くに離して 直いた非接触群では1.11倍であり, 接触群に嘗吸収の促 進が認められた。

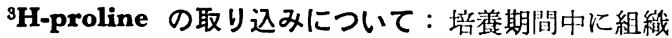

が死滅する可能性が考学られるので ${ }^{3} \mathrm{H}$-proline の取り 込みについて検討を加えた（図 5).1日目，2日目と 同程度の ${ }^{3} \mathrm{H}$-proline の取り込みが認められたのに対し て，3日目より低下傾向を示し，4 日目で急激な低下が 認められた。 このことは組織の viability が培養日数の 增加とともに低下することを意味しているものと思われ る。また，熱処理を加えた組織では全く取り込みが認め られなかった。

各種組織片の骨吸収能について : 各種組織片と歯根変 胞組織片の骨吸収能を比較したものが表 2 である。臨床 的に発赤の認められた歯肉および，炎症を起こした既往

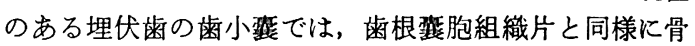
吸収の促進が認められたが，炎症の既往のない正中過剩 埋伏歯の歯小辆および, rat の肝臓では対照群と比較し て骨吸収の促進は認められなかった。

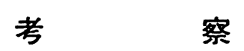

一般に買骨内蓓胞の骨吸収機構としては，炎症等の刺 激により, 砫胞の内王が元進し，その結果周囲の骨組織 が吸収するといわれている1,2)。乙かし，今回の報告に より，噩胞組織片が直接破骨細胞の関与なく，骨組織を 吸収する能力のあることが, in vitro の头験により確認 された。この吸収は組織と骨組織を接触させたという物 理的な刺激によるものでないことは図 4 より明らかであ る.さらに，培羡期間中の培地の $\mathrm{pH}$ を調べたところ， 7.1 から 7.4 の間であることより，培地が acidosis にな り，そのため骨組織が吸収されたといら可能性も考えら れない, しかも, 骨組織を凍結保存して, 骨組織の細胞 成分を死隇させているため, 破骨細胞の関与も考えにく いことから，直接襄胞壁組織が骨組織を吸収したものと 考えた。

破骨細胞による骨吸収機構を考えてみると破骨細胞は 骨表面に密着し，その間に特殊な環境を形成するといわ れている。これを電子影微鏡的に検索すると， ruffled border が骨表面に接し，この周囲に clear zone が形成 されている。破骨細胞は ruffled border より骨吸収促 進因子を放出して骨吸収を促進するといわれている ${ }^{16)}$. 骨吸収を促進する parathyroid hormone や PGs は破 骨細胞を活性化し, ruffled border で接する細胞を增加 させる。逆に骨吸収を抑制する calcitonin は細胞を減 少させ, ruffled border を平坦化するといわれている19). 雚胞組織片による骨吸収に拈いても，骨組織と組織片は 接触していることが重要であると思われる. Oguchi ${ }^{11}$ もまた，歯根吸収組織を用いた実験で，吸収組織が骨表 面に接することが重要であると報告している。しかし， 敬壁組織片がどのような形式で骨組織に接しているの か，いかなる機構で骨組織を吸収するのかは，現在のと ころ明らかでない 
では，この翼壁組織による骨吸収にどのような細胞が 関与しているのであろらか.

Eilon ら ${ }^{10)}$ は瘇濽細胞を用いて，骨吸収能を検討し， 骨転移を起こした腫序より分離された隀瘍細胞が骨組 織を吸収する能力のあることを報告している。また， Mundy ら ${ }^{12)}$ は plastic dish に付着した血中単核細胞 (単球) が骨組織を吸収する能力があること，付着しな い単核細胞（大部分リンパ球）は吸収する能力のないこ とを報告している．単球あるいは macrophage が骨組織

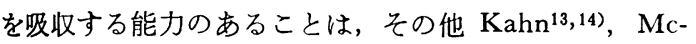

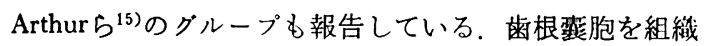
学的に調べると, 炎症性の細胞浸潤が認められる。この ことから，蕉壁組䄉による骨吸収に macrophage など の炎症性細胞が関与する可能性が十分に考えられる。さ らに，表 2 より検討例は少ないが，炎症を起こした組織 が炎症のない組織より骨吸収能があることからもこのこ とは推察される。しかし，この点に関しては, 組織学的 所見と照らしあわせてさらに検討する必要があるものと 思われる。

一般に，骨組織は破骨細胞により吸収されるといわれ ている．特に炎症における骨吸収機構としては，局所に PGs や lymphokine の一種である osteoclast activating factor が出現し，これらの特質が破骨細胞を活性化し， 骨組織を吸収するものと考えられている20)、整胞におけ る骨吸収においても，倠胞内王が上昇し擎胞が周囲の骨 組織を圧して，その刺激により骨組織内に PGs が産生 され，破骨細胞が活性化されて骨組織が吸収される可能 性が考えられる。ささらに，感染等により䈣胞壁組織自身 が PGs を産生して周团骨組織を吸収する可能性もあ る. Yamazaki ら ${ }^{21,22)}$ は歯牙移動による実験で, 矯正力 を歯牙に加えると，周囲の骨組織に PGs 様の物質が出 現し, 局所の破骨細胞数が増加することを報告してい る.さらに, Harris ら マ 9) は変壁組織を培養すると, PGs 様の物質が培地に放出され，この物質が in vitroで骨組 織を吸収することを報告している. osteoclast activating factor に関しては，今のところ明らかではない.

したがって，われわれの実験結果，および Yamazaki，

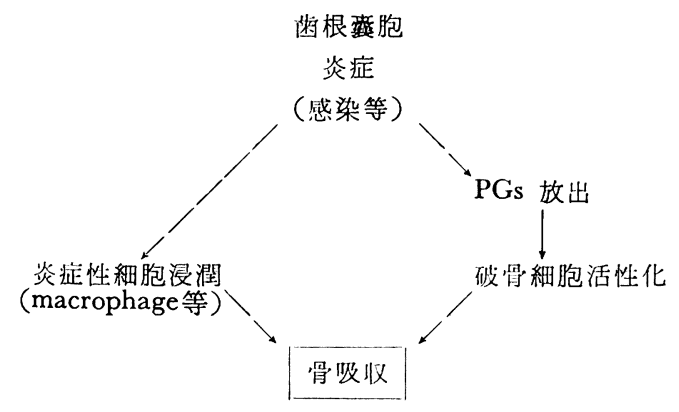

図 6 幽根絃胞による骨吸収機構（仮説）
Harris らの報告を考え合わせると，歯根裂胞による骨 吸収機構としては，今のところ図 6 のように 2 つの機構 が考えられる。しかし，これらの結果は in vitro の実 験結果および動物笑験からの推定であるので，ヒトの場 合においても同じ骨吸収の機構が存在すると結論するに はさらにデータの集積が必要であろら。

\section{結論}

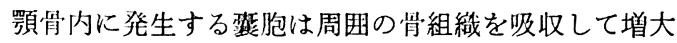
するが，局所での骨吸収機構は不明である。そこでこの 機桡を解明することを目的として，まず翌壁組織が直接 骨組織を吸収する能力があるかどうか in vitro の系に て検討した。 その結果,

1. 銮壁組織は明らかに骨吸収能を持つことが確かめ られた。

2. 熱処理をした㢣壁組織では骨吸収能は認められな かった。

3. 聚壁組織による骨吸収は，組織片が直接骨組織に 接することが必要に思われた。

4. 培養による組織の生死を ${ }^{3} \mathrm{H}$-proline の取り込み により検討したところ，3 日目より減少が認められた。

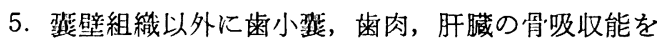
検討したところ，炎症を起こしている組織の方に骨吸収 能が高い傾向にあった.

以上のことから，歯根䗙胞組織は直接骨組織を吸収す る能力のあることが確かめられた.

\section{引 用 文 献}

1) Toller, P.A. : The osmolality of fluids from cysts of the jaws. Br Dent J 129 : 2751970.

2) Skaug, N.: Intracystic fluid pressure in nonkeratinizing jaw cysts. Int J Oral Surg 5: 59 1976.

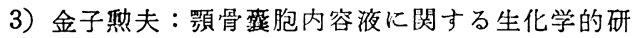
究. 日只外誌 $18: 21972$.

4) Skaug, N. : Soluble proteins in fluid from non-keratinizing jaw cysts in man. Int J Oral Surg 6: 1071977.

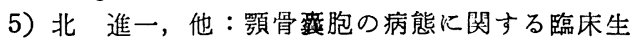
化学的研究. 日口外誌 23:21 1977.

6）鈴木 貢：顎口腔疾患の臨㦿的考察（終報）, 顎骨落胞の臨床生化学的考察 (その 6 ), 一特に 顎暴胞增大因子に関する臨床生化学的検討。口 科誌 29：460 1980 .

7) Harris, M.: The production of a bone resorbing factor by dental cyst in vitro. $\mathrm{Br} \mathrm{J}$ Oral Surg 10: 3341973.

8) Harris, M., et al.. Prostaglandin production and bone resorption by dental cysts. Nature 
245: 2131973.

9) Harris, M. : Odontgenic cyst growth and prostaglandin-induced bone resorption. Annals of the Royal College of Surgeons of England 60: 851978 .

10) Eilon, G., Mundy, G.R.: Direct resorption of bone by human breast cancer cells in vitro. Nature 276:726 1978.

11) Oguchi, H.: In vitro studies of bone resorption by the root-resorbing tissue from the bovine deciduous tissues. Bulletin of Tokyo Medical and Dental University 22: 1751975.

12) Mundy, G.R., et al.: Direct resorption of bone by human monocytes. Science 196:1109 1977.

13) Kahn, A.T., et al.: Contact mediated bone resorption by human monocytes. Science 199: 9881978.

14) Teitelbaum, S.L., et al. : Rodent peritoneal macrophages as bone resorbing cells. Calci Tiss Intl 27: 2551979.

15) McArthur, W., et al.: Bone solubilization by mononuclear cells. Lab Invest 42: 4501980.

16）小沢英浩：硬組織の超钞細構造と石灰化. 骨代 謝 8: 2271975 .
17) Wezman, F.H., et al.: Morphology of osteoclasts in resorbing fetal rat bone explants: Effects of PTH and AIF in vitro. Anat Rec 194: 3111979.

18) Schelling, S.H., et al.: Role of osteoclast in prostaglandin $\mathrm{E}_{2}$-stimulated bone resorption. A correlative morphometric and biochemical analysis. Lab Invest 42: 2901980.

19) Kallio, D.M., et al. : Ultrastructural effects of calcitonin on osteoclasts in tissue culture. J Ultrastructure Res 39: 2051972.

20) Raisz, G., et al.: Immunologic factors influencing bone resorption : Role of osteoclast activating factor from human lymphocytes and complement mediated prostaglandin synthesis. In calcium regulating hormones, eds. Talmage, R.V., et al., p145, 1975. Excerpta Medica. Amsterdam.

21) Yamazaki, K., et al. : Prostaglandin as a mediator of bone resorption induced by experimental tooth movement in rats. $\mathrm{J}$ Dent Res 59: 16351980.

22）山崎健一, 他：蒾科矯正刺激によって誘導され た内因性プロスタグランディンの骨吸収機序に ついて。骨代謝 13：329 1980. 